\title{
Könyvismertető
}

\section{Dr. Csapó János: A turizmuspolitika és turizmusirányítás elmélete és gyakorlata az Európai Unióban c. könyvéröl}

Az Akadémiai Kiadó gondozásában, a Pécsi Tudományegyetem támogatásával elkészült szakkönyv egyedülálló a maga nemében, hiszen hazánkban először foglalja össze „tágabb környezetünk”, az Európai Unió turizmusának egységes irányítása és fejlesztése érdekében kifejtett erőfeszítéseit, gondolkodásmódját és az egyes tagállamok sajátosságait.

De miért is érdemes foglalkoznunk a turizmuspolitikával? - teszi fel a kérdést a szerző és az Akadémiai Kiadó könyvismertetője. Egyrészt, mert a turizmus állandóan változó folyamatai, valamint a kereslet és kínálat, a turisták fogyasztói szokásai folyamatosan átalakulnak, befolyásolva ezzel az ágazat természeti, gazdasági és társadalmi környezetre kifejtett jótékony vagy negatív hatásait. Mindezek harmonizálása, egy irányba terelése csak átgondolt, kidolgozott és megfelelően végrehajtott turizmuspolitika megléte esetén lehetséges. Másrészt - ahogy erre a fent hivatkozott könyvismertető is rávilágít - „,a politika tanulmányozásával megérthetjük a politikai döntések alakulásának mikéntjeit és hatásait, valamint információt kaphatunk a felmerülő problémák megoldása kapcsán, amelyet beépíthetünk a politika folyamatába, továbbá megérthetjük a politika és a tervezés folyamatának érdekeit és értékeit." (https://akademiai.hu/1828/gazdasag/turizmus/a_turizmuspolitika_es_turizmusiranyitas_elmelete_es_gyakorlata_az_europai_unioban\#prettyPhoto)

A mű átfogó célja az, hogy elősegítse a turizmus elméleti alapjaiból ismert tudás, valamint a turizmusirányításban szerzett tapasztalat gyakorlati alkalmazását. Ugyanakkor a Szerző célként fogalmazta meg a turizmuspolitika szerepének, jelentőségének elméleti ismertetésén, fogalmi hátterének elemzésén és bemutatásán túl annak gyakorlati aspektusból történő feldolgozását, így a könyv megalapozó és átfogó elméleti fejezetei után betekintést nyerhetünk a globális turizmus trendjeibe, a nemzetközi turizmus legfontosabb szervezeteinek müködésébe, az Európai Unió turizmuspolitikájába. Különösen kiemelésre kerül az, hogy a turizmuspolitika hogyan határozza meg a hosszú és középtávú fejlesztési célokat, hogyan alakítja ki a fejlesztési célok eléréséhez szükséges feltételeket, illetve ösztönzi és szabályozza az idegenforgalmi folyamatokat. A Szerző mindezeket a szakkönyv bevezetőjében világosan deklarálja.

A szakkönyv elsőként a globális turizmus térbeli megoszlása, trendjei, mai helyzete témakörökben mutatja be a turizmuspolitika alapjául szolgáló nemzetközi idegenforgalmi folyamatokat, kurrens trendeket, amelyeket az egyes szakmai szervezeteken túl úgy az európai uniós, mint a nemzeti szakpolitikai döntéshozók is figyelembe kell vegyenek. Képet kaphatunk a turisztikai teljesítmény nemzetközi mutatószámairól, annak területi eloszlásáról illetve gazdasági hatásairól, de a szerző beszámol a könyv területi aspektusát adó Európa (ezen belül az Európai Unió) helyzetéröl és jelentőségéről is. Külön alfejezetet kap a nemzetközi turizmus keresleti trendjeinek értékelése, hiszen leginkább ez befolyásolhatja egy ország vagy országcsoport turizmuspolitikájának alakulását.

A mű egyik legértékesebb és legmélyebben elemzett része a Turizmuspolitika, szabadidő-politika, a turizmus irányítás elméleti alapjainak bemutatása c. fejezet. A szakirodalom elemzése kapcsán megállapítható, hogy nemzetközi szinten, de Magyarországon különösen mindeddig hiánypótlónak számít a téma átfogó formában történő feldolgozása, a kutatások döntő része korábban inkább a területi tervezés regionális folyamataival foglalkozott.

A könyv írójának kiváló angol nyelvtudása lehetővé tette azt, hogy magyar nyelvű szakirodalmak mellett jelentős mennyiségü idegen nyelven megjelent müvet dolgozzon fel, több esetben a fogalmak a szerző saját fordításában jelennek meg. A turizmuspolitika átfogó elméleti elemzésén túl betekinthetünk a turizmuspolitika tudományrendszertani elhelyezésébe is (Turizmuspolitika helye a turizmus rendszerében és környezetében), de részletesen bemutatásra kerülnek a turizmuspolitikával foglalkozó hazai és nemzetközi kutatók és kutatási irányok is. 
A szakkönyv címéhez leginkább harmonizáló témák a 3. és 4. fö fejezetben jelennek meg. A turizmuspolitika szerepéről és általános feladatairól, valamint a turizmuspolitikát alakító nemzetközi és hazai szervezetekről, különösen az állami és nem állami szerepvállalásról, annak okairól és tevékenyégéről, a tervezési szintekről, a turizmuspolitika alakításának szereplőiről és a tervezés folyamatairól ír a szerző, mindvégig megőrizve az olvasmányos, ugyanakkor tudományos stílust annak érdekében, hogy a száraznak tủnő anyag könnyen elsajátíthatóvá váljon. Ezt segítik elő a szerkezetileg is elkülönülő, keretbe foglalt esettanulmányok.

Mint korábban jeleztem, a téma elméleti hátterének elemzésén és bemutatásán túl annak gyakorlati aspektusból történő feldolgozása is cél volt. Ezt hivatott szolgálni Az Európai Unió turizmust érintő intézkedései, turizmussal kapcsolatos tevékenysége c. fejezet, amely integráció turizmust érintő intézkedéseinek historikus áttekintése, a legfőbb mérföldkövek kiemelése után részletesen bemutatja az Európai Unió tagállamaiban a turizmuspolitika jellemzőit és gyakorlatát, így a turizmus irányításának szervezeti felépítését és a turizmustervezés főbb stratégiai programjait, irányait.

A Mellékletben kerülnek elhelyezésre eredeti szövegezéssel a témához kevésbé direkt módon, ugyanakkor mindenképp kötődő dokumentumok, amelyek a megértésben segítenek, de nem képezik a szakkönyv törzsanyagát.

A Felhasznált irodalom bőséges, aktuális és naprakész. A legfontosabb nemzetközi és hazai alapművek és egyéb tételek szinte kivétel nélkül szerepelnek benne, így ez a fejezet iránymutató bibliográfiaként is megállja a helyét. Összefoglalásul a recenzor csak ismételni tudja: olyan stabil elméleti alapokon nyugvó, ám mégis gyakorlatias munka született Csapó János tollából, amely szakkönyvként és tankönyvként egyaránt megállja a helyét.

A turizmuspolitika és turizmusirányítás elmélete és gyakorlata az Európai Unióban c. könyv föbb eredményei a következők:

- A feldolgozás átfogó szemlélete és gyakorlati elemekkel, valamint esettanulmányokkal alátámasztott mondanivalója rendkívül sokoldalúan mutatja be a téma legalapvetőbb összefüggéseit és kölcsönös összefüggésrendszerét.

- A könyv gyakorlati, alkalmazható ismereteket közöl, de a tapasztalatokat stabil elméleti keretekbe is foglalja. Ez nagyon hasznos, hiszen az ismeretlen fogalmak tisztázódnak, illetve többféle értelmezést is kaphatnak.

- A szerző szakirodalmi ismerete átfogó, szerteágazó felfogása beleillik a nemzetközi irányzatokba.

Külön elismerés illeti a szerzőt azért, mert a turizmusirányítás teljes folyamatát a turizmus aktuális helyzetéhez és a felsőoktatási képzések igényeihez igazodva, nemzetközi, európai és nemzeti viszonyokat figyelembe véve tekintette át. Ezért véleményem szerint a mủ hasznos szakkönyvként szolgál a turisztikai felsőoktatásban dolgozó, a turizmus iránt érdeklődő vagy elkötelezett oktatókon, kutatókon túl a turisztikai irányultságú mesterképzésben és doktori képzéseken résztvevők számára, de vélhetően a szakpolitikai döntéshozók, a különbözö szinteken a turizmuirányítással foglalkozó szervezetek (TDM, megyei, illetve települési önkormányzat stb.), illetve a területi tervezök is örömmel forgathatják a kötetet.

A recenzor könyvismertetését azzal zárja, hogy megtiszteltetés volt számára jelen sorok megírása.

Bujdosó Zoltán

Pécsi Tudományegyetem 